\title{
Tanggapan Pemilih Pemula Terhadap Caleg Perempuan Pada Pemilu Legislatif (PILEG) 2019
}

\author{
Ni Luh Putu Suciptawati ${ }^{*}$, I Komang Gde Sukarsa ${ }^{1}$, Eka Nila Kencana ${ }^{1}$ \\ ${ }^{1}$ Universitas Udayana, Indonesia
}

\author{
A R T I C L E IN F O \\ Article history: \\ Received 09 September \\ 2020 \\ Accepted 10 Desember \\ 2020 \\ Available online 31 \\ Desember 2020 \\ Kata Kunci: \\ Caleg Perempuan; Pemilih \\ Pemula; Pemilu Legislatif \\ Keywords: \\ Women Candidates: \\ Beginner Voter's; \\ Legislative Election
}

\begin{abstract}
A B S T R A K
Representasi perempuan dalam legislatif sangatlah penting, keberadaan legislator perempuan diharapkan dapat meningkatkan peran perempuan dalam kebijakan publik seperti pengentasan kemiskinan, kemajuan pendidikan, dan dibidang kesehatan. Penelitian ini bertujuan untuk melihat bagaimana persepsi pemilih pemula terhadap partisipasi perempuan dalam pemilihan legislatif 2019. Data penelitian berupa data primer dengan menyebarkan kuesioner kepada 300 responden pemilih pemula di Denpasar dengan menggunakan purposive sampling. Metode analisis yang digunakan adalah regresi logistic biner. Hasil penelitian menunjukkan bahwa dari 300 responden 235 tidak setuju dengan kandidat perempuan, hanya 65 yang memilih kandidat perempuan. Faktor yang berpengaruh terhadap cara berpikir responden dalam memilih caleg adalah pendidikan dan keaktifan dalam berorganisasi.
\end{abstract}

\section{A B S T R A C T}

Women's representation in the legislative body is important, Women's legislature is expected to increase the role of women in public policy such as poverty alleviation, education parity, and health care. This study aims to see how perceptions of beginner voters on the participation of women in the 2019 legislative election. The data used in this study is the primary data collected using a questionnaires distributed to 300 beginner voter in Denpasar using porvosive sampling. The study used logistic biner regression. The results showed that out of 300 respondents 235 disagreed with female candidates, only 65 agree female candidates. Faktors that influence respondents in choosing legislative candidates are education and organizational activity.

*Corresponding author.

E-mail addresses: suciptawati@unud.ac.id 


\section{Pendahuluan}

Tanggal 17 April 2019 rakyat Indonesia melaksanakan pesta demokrasi lima tahunan yaitu Pemilihan Umum (Pemilu). Berbeda dengan pemilu sebelumnya pada pemilu kali ini pemilihan presiden (Pilpres) dilaksanakan bersamaan dengan pemillhan anggota legislatif (Pileg) baik DPR Pusat, DPD maupun anggota DPR daerah. Pelaksanaan pemilu serentak 2019 berdasarkan Keputusan Mahkamah Konstitusi Nomor 14/PUU-XI/2013. Berdasarkan UU No. 2 Tahun 2008 pendirian partai politik diharuskan menyertakan keterwakilan perempuan minimal 30\% dalam pendirian maupun dalam kepengurusan di tingkat pusat. Menurut (Subono, 2009) hadirnya gagasan representasi perempuan dalam politik karena: 1) berkenaan dengan keadilan dan kesetaraan gender yang sudah diatur dalam konstitusi; 2) women inters, banyak issue-isue spesifik yang hanya bisa direpresentasikan perempuan, hanya perempuan yang tahu pasti apa yang menjadi masalah perempuan; 3) perempuan membuat perbedaan. dalam banyak kasus gaya politik laki-laki dan perempuan berbeda; dan 4) kehadiran aktivis perempuan dalam parlemen layak dijadikan panutan dalam berpolitik.

Target angka 30\% keterwakilan perempuan dalam parlemen masih jauh dari harapan, ini dapat dilihat dari hasil Pemilu tahun 2014 proporsi anggota parlemen perempuan hanya 17,1\%, jumlah ini menurun dibandingkan dengan hasil Pemilu tahun 2009 yang mana proporsi anggota parlemen perempuan mencapai 18,2\% ( Menteri PPA RI, 2015). Perkembangan jumlah calon anggota legislative ( Caleg ) perempuan DPR RI di Pemilu pada Era Reformasi dapat dilihat pada Tabel 1.

Tabel 1. Persentase Jumlah Caleg Perempuan DPR RI dan Caleg Perempuan Terpilih di Pemilu Era Reformasi

\begin{tabular}{lccrc}
\hline & \multicolumn{4}{c}{ Tahun } \\
\cline { 2 - 5 } & 1999 & 2004 & 2009 & 2014 \\
\hline $\begin{array}{l}\text { Caleg } \\
\text { Perempuan }\end{array}$ & $19 \%$ & $33 \%$ & $34,7 \%$ & $37 \%$ \\
\hline $\begin{array}{l}\text { Caleg } \\
\begin{array}{l}\text { Perempuan } \\
\text { terpilih }\end{array}\end{array}$ & $9 \%$ & $11 \%$ & $18 \%$ & $17 \%$ \\
\hline
\end{tabular}

Sumber : (KPU, 2014)

Memperhatikan tabel 1, terlihat walaupun persentase caleg perempuan pada pileg selalu memenuhi syarat minimal kuota perempuan (30\%), tetapi yang terpilih masih belum memenuhi harapan. Ini menunjukkan tingkat partisipasi perempuan dalam politik masih rendah. Belum dipenuhinya kuota $30 \%$ bisa jadi karena kekuatan politik perempuan belum terkonsolidasi dengan baik, selain itu karena masyarakat Indonesia yang sebagian besar menganut budaya patrilinear sehingga terjadi bias gender, hal ini sesuai dengan pernyataan (Yudha, 2018) bahwa kurangnya keterlibatan perempuan dalam politik bukan semata-mata karena perempuan enggan masuk dalam ranah politik, tetapi itu semua merupakan hasil konstruksi bias gender. Perempuan dipersepsikan sebagai tidak patut dalam politik, tidak mau, tidak berani dan tidak mampu terjun dalam politik. Dilain pihak laki-laki 
dikonstrusikan sebagai orang yang mampu dan pantas terjun di kancah politik dan urusan publik lainnya. Menurut (Agustina, 2014) kurangnya perempuan yang terpilih masuk parlemen berdampak pada rendahnya nilai indikator Indek Pembangunan Manuisa (IPM), indeks pemberdayaan gender (IDG) dan Indeks Pembangunan Gender (IPG). IDG menunjukkan apakah perempuan dapat secara aktif berperan serta dalam kehidupan ekonomi dan politik. IDG menitikberatkan pada partisipasi, dengan cara mengukur ketimpangan gender di bidang partisipasi politik, pengambilan keputusan (sosial) dan aksesibilitas terhadap sumber daya ekonomi. IDG terdiri tiga dimensi yakni keterwakilan di parlemen dengan indikator persentase anggota parlemen laki-laki dan perempuan, pengambilan keputusan dengan indikator persentase pejabat tinggi, manajer, pekerja profesional dan teknisi, distribusi pendapatan dengan indokator persentase upah buruh non pertanian disesuaikan antara laki-laki dan perempuan. dari sini jelas terlihat rendahnya keterwakilan pereempuan di parlemen salah satu faktor yang menyebabkan IDG Indonesia menjadi rendah.

Belum terpenuhinya representasi politik perempuan di parlemen tidak saja terjadi di Indonesia, tetapi juga menjadi masalah internasional. Menurut (Wardani, 2011) pada tahun 2011 ada 6 negara yang tidak mempunyai wakil perempuan di parlemen nasional yaitu: Arab Saudi, Micronesia, Nauru, Solomon Islands, Palau, Tuvalu dan Qatar. Untuk kasus Indonesia, variabel sosioekonomi diduga memiliki kontribusi terhadap keterpilihan perempuan di parlemen. Kondisi pembangunan yang belum merata dan kondisi ekonomi berekontribusi terhadap akases perempuan pada kegiatan politik khususnya untuk teriplih menjadai anggota legislatif.

Penelitian lain mengenai keterwakilan perempuan dalam DPR pernah dilakukan oleh (Adelina, 2016) menyatakan bahwa di DPRD Provinsi Sumatra Utara dari 100 anggota legeslatif terdapat 16 orang perwakilan perempuan. Salah satu kendala belum tercapainya kuota 30\% anggota legislatif perempuan adalah tergantung dari kebijakan partai pengusung serta dari masyarakat sebagai pemilih.

Bagaimana dengan Caleg Perempuan di Bali?. Perempuan Bali lebih banyak melaksanakan kegiatan keagamaan baik di keluarga, di banjar maupun di desa, kegiatan ini dikenal dengan istilah ngayah. Dengan konsep ngayah tersebut dapat menjadikan perempuan Bali sebagai perempuan yang kuat, pekerja keras dan pandai mengatur waktu. Walaupun perempuan Bali terkenal pandai mengatur waktu, tapi itu belum mampu membuat perempuan Bali terjun ke kancah politik. Semuanya tidak terlepas dari seperti umumnya dalam masyarakat yang menganut paham budaya patriarki dalam kehidupan sosial masyarakat Bali pengambilan keputusan penting dimasyarakat didominasi kaum laki-laki, perempuan hanya sebagai pelaksana keputusan tersebutPenelitian yang dilakukan (Karika, 2017) tentang eksistensi perempuan Bali dalam berpolitik menyebutkan bahwa Pada pemilihan umun 2014 partisipasi perempuan pada tahap pencalonan (Caleg) DPRD Provinsi Bali cukup mengembirakan yaitu dari 461 caleg yang terdaftar ada sebanyak 168 orang(37\%) caleg perempuan. Tingginya persentase caleg perempuan tidak diimbangi dengan perolehan suara setelah pemilihan . Jumlah pada tahap proses pencalonan tetap dengan 
setelah terpilih menjadi anggota Legislatif (DPRD) sangat jauh berbeda, dari 168 orang perempuan yang berpartisipasi dalam pencalonan tetapi yang terpilih menjadi wakil rakyat hanya 5 orang. Dibandingkan dengan keterwakilan politisi laki-laki dari 55 orang ketentuan yang menjadi anggota DPRD Provinsi Bali, laki-laki terwakili 50 kursi di DPRD provinsi sedangkan perempuan hanya mengisi 5 kursi (9\%). Hasil penelitian ini menunjukkan bahwa tidak dipenuhinya kuota perempuan sebanyak 30\%, bukan karena kurangnya caleg perempuan, tetapi karena kurangnya kesadaran masyarakat dalam memilih perempuan untuk duduk di parlemen. Kultur adat dan budaya di Bali yang menganut paham Patriarkhal belum terbiasa memberikan perempuan untuk terlibat disektor publik, apalagi sektor politik. jadi harapan mengisi kuota $30 \%$ keterwakilan perempuan dalam parlemen masih jauh dan sangat susah untuk dilakukan.

Pada pemilu tahun 2019 ada 16 partai politik yang ikut berkontestasi dengan rincian 12 partai lama dan 4 partai baru. Dengan bertambahnya partai peserta pemilu berarti pilihan Caleg juga bertambah. Partai-partai tersebut berharap mendapat dukungan dari para pemilih pemula, mengingat pemilih pemula pada tahun ini diperkirakan sebanyak 5.035.887 jiwa.

Pemilih Pemula adalah Warga Negara Indonesia (WNI) yang pada hari pemungutan suara sudah genap berusia 17 tahun atau lebih, atau sudah/pernah menikah, serta sebelumnya belum pernah ikut memberikan suaranya karena ketentuan Undang-Undang Pemilu. Tidak sedikit pemilih pemula belum memiliki pengetahuan politik praktis yang luas, sehingga mereka sering berpikir tidak rasional dan cenderung ikutikutan, mereka memilih karena ikut teman atau ikut orang tua. Partai-partai politik harus dapat merangkul pemilih pemula karena mereka memiliki karakter yang unik dibandingkan dengan pemilih yang sudah pernah ikut memilih pada pemilu sebelumnya.

Selanjutnya (Kelana, 2019) mendefinisikan karakteristik pemilih pemula sebagai berikut: 1) Belum pernah memilih atau melakukan penentuan suara di dalam TPS ; 2) belum memiliki pengalaman memilih; 3) memiliki antusias yang tinggi; 4) kurang rasional; 5) merupakan pemilih muda yang masih penuh gejolak dan semangat, dan apabila tidak dikendalikan akan memiliki efek terhadap konflik-konflik sosial di dalam Pemilu; 6) menjadi sasaran peserta pemilu karena jumlahnya yang cukup besa; 7) memiliki rasa ingin tahu, mencoba, dan berpartisispasi dalam pemilu, meskipun kadang dengan bebagai latar belakang yang rasional dan semu. Karena karekternya yang unik pemilih pemula selalu menjadi incaran kontestan pemilu, mereka sangat rentan dipengaruhi dan dijaring oleh parpol.

Kedudukan dan makna strategis pemilih pemula dalam pemilu adalah: 1) pemilih pemula merupakan kelompok yang jumlahnya relative banyak dalam setiap pemilu, 2) merupakan satu segmen pemilih yang sulit diatur dan ditebak kemana arah pilihannya, 3) ada kekawatiran mereka akan menjadi golput karena banyaknya pilihan partai politik, 4) menadi sasaran partai politik untuk mempengaruhi dengan mengklaim sebagai organisasi yang cocok menjadi penyalur aspirasi pemilih pemula (Prasetyo, 2019). 
Merujuk (Zamhasari, 2017) Sebagai pemilih pemula yang masih idealis pergantian pimpinan politik diharapkan membawa perubahan yang positif dan lebih baik dari periode sebelumnya. Berikut adalah harapan-harapan mereka : 1) terciptanya lapangan pekerjaan baru, 2) meningkatnya kesejahteraan terutama dibidang ekonomi, 3) perbaikan mutu pendidikan, 4) kemudahan akses transportasi, 5) yang tak kalah penting adalah penumpasan segala bentuk korupsi

(Hartono, Y. dan Putri, E.M.C, 2015) meneliti 172 responden yang merupakan pemilih pemula pada pemilu tahun 2014 , sebanyak 81,97 \% setuju bahwa pemilihan umum merupakan sarana dalam mewujudkan demokrasi, sebagai sarana mewujudkan hak politik. Sebagian besar siswa juga memandang bahwa anggota legislative (DPR, DPD dan DPRD) dan presiden yang ada sekarang belum mampu melaksanakan tugas dan fungsinya seperti yang diharapkan.

Menurut (Nur Wardhani, 2018) faktor pendukung pemilih pemula dalam pemilu adalah: karena ada rangsangan dari media masa atau elektronik, pemilih pemula sadar akan hak pilihnya sehingga mereka bersedia datang ke TPS-TPS, mereka berpartisipasi dalam pemilu berdasarkan keinginan sendiri tanpa paksaan dari siapapun. Sedangkan faktor penghambat partisipasi pemilih pemula dalam pemilu diantaranya karena: adanya larangan dari orang tua, kesibukan mereka, perasaan rendah diri sehingga mereka tidak mampu datang ke TPS untuk memberikan hak suaranya.

(Saputra, 2017) merekomendasikan untuk memotivasi pemilih pemula ikut berperan aktif dalam pemilu diperlukan dukungan keluarga, lingkungan tempat tinggal dan peran tokoh masyarakat, selain itu diharapkan pemerintah menyediakan fasilitas-fasilitas pendukung kegiatan pemilih pemula dalam dunia politik serta pemberian pendidikan politik yang dapat merangsang keinginan pemilih pemula untuk berpartisipasi dalam pemilu.

Partisipasi pemilih pemula dalam pileg 2019 dapat mempengaruhi suara bagi caleg yang ikut berkontestasi dalam pileg, untuk itu perlu dilakukan penelitian kearah manakah suara pemilih pemula? Apakah gender mempengaruhi pilihan mereka dalam pileg? Sebagai variabel penelitian yang digunakan adalah: kondisi ekonomi pemilih yang direpresentasikan dengan pekerjaan orang tua; kondisi demografi yang meliputi pendidikan dan umur pemilih; Interaksi sosial dalam hal ini apakah pemilih aktif di lingkungan sekolah/universitas, organisasi kepemudaan, dll. Tujuan penelitian ini adalah untuk melihat bagaimana tanggapan pemilih pemula terhadap caleg perempuan

\section{Metode}

Penelitian ini dilakukan di kota Denpasar, selama 8 bulan, dimulai pada bulan Pebruari 2019 hingga September 2019. Populasi penelitian adalah pemilih pemula yang ada di kota Denpasar, sebagai sampel diambil 300 orang responden yang sudah melaksanakan hak pilihnya pada pemilu 2019. Teknik pengambilan sampel yang digunakan adalah purposive sampling yaitu suatu penarikan sampel dengan pertimbangan. Pertimbangan yang kami gunakan disini adalah responden merupakan pemilih yang baru pertama kali ikut memilih pada pemilu tahun 2019. Penelitian ini merupakan kajian 
deskriftif kualitatif sekaligus kuantitatif. Instrumen penelitian berupa kuesioner yang disebar kepada responden yang menjadi sampel penelitian. Untuk keperluan kajian kualitatif pada kuesioner diberikan pertanyan terbuka yang harus dijawab responden dengan sejujurnya.

Analisa data yang digunakan dalam kajian kuantitatif adalah tabulasi silang dan pendekatan analisis regresi logistik biner. Tabulasi silang digunakan untuk melihat korelasi antara masing-masing variable prediktor dengan variable respon. Analisis regresi logistik biner adalah metode regresi di mana variabel respon $Y$ dalam bentuk kategorik biner atau dikotomi (yang mempunyai dua kemungkinan nilai) dalam kasus ini jenis kelamin caleg pilihan responden. Secara umum, model probabilitas regresi logistik yang melibatkan beberapa variabel prediktor $\mathrm{x}$ dinyatakan dengan

$$
\pi(x)=\frac{\exp \left(\beta_{0}+\beta_{1}+\ldots+\beta_{6}\right)}{1+\exp \left(\beta_{0}+\beta_{1}+\ldots+\beta_{6}\right)}
$$

Fungsi (1) merupakan fungsi non linier. Hubungan antara variable respon dengan variable prediktor akan mudah dilihat jika fungsi yang terbentuk merupakan fungsi linier. Agar Untuk memperoleh fungsi yang linier langkah yang dapat dilakukan adalah menggunakan transformasi logit. Bentuk logit dari $\pi(x)$ dapat dinyatakan sebagai $g(x)$

yaitu: $g(x)=\ln \left(\frac{\pi(x}{1-\pi(x)}\right)=\beta_{0}+\beta_{1}+\beta_{2}+\ldots .+\beta_{6}$

$\mathrm{g}(\mathrm{x})$ disebut dengan fungsi logit model regresi logistic biner dengan $\mathrm{k}$ variabel predictor. Penduga parameter pada regresi logistik dilakukan dengan menggunakan Method of Maximum Likelihood (MLE). (Hosmer, D.W. and Lemeshow,S., 2000). Variabel respon (Y) dalam penelitian ini yaitu gender caleg pilihan responden, dan variabel prediktor sebagai berikut: Jenis kelamin responden (X1), Umur responden (X2), pendidikan responden (X3), pekerjaan ayah (X4), pekerjaan ayah (X5) dan keaktivan dalam organisasi (X6)

Langkah-langkah analisis data pada penelitian ini adalah:

1) Penyebaran kuesioner kepada responden

2) Membuat tabulasi silang antara variabel respon dengan tiap-tiap variabel predictor

3) Melakukan uji signifikansi parameter secara simultan dengan menggunakan statistik uji G

4) Melakukan uji signifikansi parameter secara parsial dengan menggunakan statistik uji Wald untuk mengetahui koefisien paramater yang berpengaruh secara individual terhadap model.

Hipotesis Uji Wald:

$H_{0}: \beta_{g 1}=0$

$H_{1}: \beta_{g 1} \neq 0$

Statistik uji pada uji Wald: 


$$
W=\frac{\widehat{\beta}_{g 1}}{s \widehat{\beta}_{g 1}} \sim \mathrm{N}(0,1)
$$

Dengan $g=1,2, \ldots ., \mathrm{G}-1$

Tolak $\mathrm{H}_{0}$ jika nilai statistik uji Wald $<\left|\mathrm{Z}_{(\alpha / 2)}\right|$ atau nilai $p$-value $<\alpha$.

5) Melakukan uji kecocokan model regresi logistik binar diukur dengan nilai chi-square dan uji Hosmer and Lemeshow

6) Menginterpretasikan odds rasio yang diperoleh.

\section{Hasil dan pembahasan}

Pelantikan anggota DPR RI sudah dilaksanakan pada tanggal 1 Oktober 2019 dari 575 anggota DPR terpilih periode 2019-2024 sebanyak 118 kursi atau 21 persen merupakan anggota dewan perempuan. Jumlah tersebut meningkat 22 persen dari pemilu sebelumnya yang hanya mengisi sebanyak 97 kursi. Hasil rapat pleno rekapitulasi suara Komisi Pemilihan Umum (KPU) Provinsi Bali menunjukkan total jumlah pemilih di Bali sebanyak 3.220.470 orang dengan 1.253 .378 merupakan pemilih pemula. Pada hari pemilihan pemilih yang menggunakan hak pilihnya 2.606.201 orang, dari jumlah tersebut, total suara sah sebanyak 2.313.366 dan suara tidak sah sebanyak 292.835. Jumlah anggota DPR RI tahun 2019-2024 dari Bali sebanyak 9 orang, kesembilan orang tersebut semuanya laki-laki. Hasil ini menunjukkan sampai saat ini keterwakilan perempuan di legislatif masih sangat rendah, laki-laki masih mendominasi pilihan masyarakat Bali sebagai wakil mereka di DPR RI. Sebaliknya untuk kursi DPRD Bali terjadi peningkatan jumlah anggota dewan perempuan jika pada pileg periode sebelumnya hanya ada 5 orang anggota dewan perempuan yang duduk di DPRD Bali, kini jumlah anggota dewan perempuan yang lolos dan duduk sebagai anggota DPRD Bali periode 2019-2024 meningkat menjadi 9 orang (27\%), dengan rincian caleg PDI Perjuangan 6 orang, Partai Solidaritas Indonesia (PSI), Partai Golkar dan Partai Demokrat masing-masing satu orang. Hasil yang cukup meggembirakan sudah hampir mendekati kuota 30\% keterwakilan perempuan dalam parlemen sesuai dengan UU No. 2 Tahun 2008. Secara keseluruhan jumlah anggota dewan perempuan di Bali baik untuk tingkat Provinsi maupun kabupaten kota sebanyak 52 orang dengan sebaran sebagai berikut.

Tabel 2. Sebaran Jumlah Anggota dewan Perempuan Tingkat Provinsi Bali dan Kabupaten/Kota Seluruh Bali

\begin{tabular}{lrr}
\hline \multicolumn{1}{c}{ Daerah } & Jumlah Anggota dewan & Perempuan \\
\hline Provinsi Bali & 55 & $9(16,36 \%)$ \\
Jembrana & 35 & $7(20,00 \%)$ \\
abanan & 40 & $10(25,00 \%)$ \\
Badung & 40 & $8(20,00 \%)$ \\
Denpasar & 45 & $2(4,44 \%)$ \\
Gianyar & 40 & $2(5,00 \%)$ \\
Bangli & 30 & $0(0,00 \%)$ \\
Klungkung & 30 & $7(2,33 \%)$ \\
Karangasem & 45 & $2(4,44 \%)$ \\
\hline
\end{tabular}


Melihat hasil pileg tahun 2019 di Bali keterwakilan perempuan di legislatif periode 2019-2024 sepertinya tidak mengalami perubahan yang siginfikan dibandingkan periode 2014-2019, bahkan di kabupaten Bangli tidak ada satupun perempuan yang duduk di legislatif. Hasil yang menggembirakan ada di kabupaten Tabanan keterwakilan perempuan mulai meningkat walaupun belum mencapai 30\%. perempuan di kabupaten/ kota yang lain. Merujuk hasil pada tabel 2 dapat dikatakan partai politik belum mampu menyiapkan kader perempuan yang bisa duduk di legislatif. Tentunya ini merupakan pekerjaan rumah bagi partai-partai politik untuk lebih menyiapkan kader-kader perempuan yang dapat dipercaya masyarakat, meningkatkan skill/ pengetahuan dari setiap kader-kader perempuan. Selain itu kader-kader perempuan harus lebih sering terjun ke masyarakat, berdiskusi dengan generasi muda, atau dapat juga menuangkan gagasan-gagasan yang berguna untuk kemajuan bangsa lewat media-media social. Semakin sering kader perempuan muncul dimasyarakat harapannya mereka semakin dikenal dan masyarakat bias yakin untuk memilih mereka sehingga pada pileg lima tahun yang akan datang syarat $30 \%$ keterwakilan perempuan di legislatif dapat terpenuhi.

Organisasi perkumpulan parlemen se-dunia/Inter-Parlimentary Union (IPU) menyatakan peringkat keterwakilan perempuan di parlemen Indonesia ada di urutan 106 dunia, dengan rasio 17,1 persen perempuan dari total 560 kursi di DPR (Prihartini E. , 2016). Menurut (Krook, 2010) beberapa alasan mengapa lebih sedikit perempuan daripada laki-laki yang dipilih dalam suatu pemilu diantaranya adalah : kurang tersedianya aspirasi perempuan, tidak terpenuhinya kualifikasi perempuan untuk mencalonkan diri untuk jabatan politik, preferensi kandidat laki-laki lebih banyak dibandingkan kandidat perempuan. Sanbonmatsu (2006) dalam (Krook, 2010 ) menyatakan peningkatan jumlah perempuan dalam politik dapat terjadi jika terjadi perubahan signifikan dalam sumber daya dan motivasi perempuan untuk melakukan kampanye politik yang efektif. Dorongan untuk perubahan harus datang dari perempuan itu sendiri. jika perempuan ingin maju harus bisa mengaktalisasikan diri agar dikenal oleh masyarakat secara luas.

Dari hasil menyebarkan kuesioner kepada 300 responden pemilih pemula di Kota Denpasar dapat dilihat orientasi pilihan mereka masih pada caleg laki-laki seperti yang ditampilkan pada Tabel 3.

Tabel 3. Frekuensi Caleg Pilihan Responden

\begin{tabular}{|l|r|r|}
\hline \multicolumn{1}{|c|}{ Caleg } & Freqkuensi & \multicolumn{1}{c|}{ Persen } \\
\hline perempuan & 65 & 21,7 \\
Laki-laki & 235 & 78,3 \\
Total & 300 & 100,0 \\
\hline
\end{tabular}

Sumber: data diolah (2019)

Dari Tabel 3 tampak bahwa responden lebih menyukai caleg laki-laki dibandingkan caleg perempuan. Alasan responden lebih memilih caleg laki-laki bukan caleg perempuan diantaranya: 1) jumlah caleg perempuan sedikit yang terkesan hanya memenuhi kuota $30 \%, 2$ ) laki-laki lebih cocok sebagai pemimpin, 3) perempuan Bali selain sibuk mengurus rumah tangga juga disibukkan dengan kegiatan adat dan menyama braya sehingga sulit 
membagi waktu untuk berpolitik, 4) dengan kodratnya yang lemah lembut perempuan mudah terbawa perasaan serta kurang tegas dalam mengambil keputusan, 5) alasan lain mengapa responden tidak memilih caleg perempuan karena minimnya informasi tentang profil caleg perempuan yang ada, tidak ada sosialisasi ke banjar-banjar. Selama masa kampanye tampak yang sering melakukan sosialisasi ke banjar-banjar lebih banyak caleg laki-laki.

Pernyataan responden-responden yang tidak setuju dengan caleg perempuan tidak jauh berbeda dengan hasil penelitian ( Ras A Gelgel, N.M. dan Apriani, K.D., 2019) menyatakan hambatan caleg perempuan yang bertarung di Bali pada Pemilu 2019 diantaranya karena: 1) kemampuan finansial yang terbatas, 2) kurangnya pengalaman berpolitik, 3) jaringan sosial yang terbatas, 4) keterbatasan ruang gerak dan waktu, 5) rendahnya motivasi perempuan dalam berkarier dipolitik. Selain itu rendahnya keterpilihan caleg perempuan di Bali karena terdapat diskriminasi partai dalam memilih perempuan untuk masuk dalam daftar caleg tetap. Diskriminasi akses mesin partai diduga kuat berhubungan dengan direct dan imputed discrimination yang telah diakui oleh para selector di partai politik. Yang terjadi di Bali lebih banyak Partai politik yang melamar kandidat caleg perempuan dibandingkan memilih kandidat perempuan yang melamar. Hambatan-hambatan yang dikemukan tersebut menyebabkan caleg perempuan sulit bersosialisasi , sehingga kurang dikenal dimasyarakat.

Dilain pihak alasan responden yang setuju dengan perempuan duduk di legislative diantaranya:1) emansipasi perempuan sudah saatnya perempuan tampil memperjuangkan hak-haknya, hanya perempuan yang lebih tahu apa yang dibutuhkan perempuan saat ini, 2) karena kepribadian caleg yang dipilih (pintar, cerdas, hebat, rajin, bertalenta, lembut, sopan,cara berpikir yang logis), 3) perempuan lemah lembut menjadi lebih tenang, 4) adil, berkarisma, cantik dan berpendidikan tinggi.

Kodrat perempuan yang lemah lembut dapat menjadi alasan responden memilih caleg perempuan, tetapi juga menjadikan alasan responden untuk tidak memilih caleg perempuan. Responden yang setuju dengan caleg perempuan berpendapat dengan kodratnya yang lemah lembut perempuan bisa lebih tenang dalam mengambil keputusan, sebaliknya yang tidak setuju mengagap perempuan yang lemah lembut akan mudah terbawa perasaan sehingga dalam mengambil keputusan tidak rasional.

Hasil wawancara mendalam dengan salah seorang responden perempuan yang berusia 18 tahun mengatakan dia tidak memilih caleg perempuan karena minimnya informasi tentang caleg perempuan. Mereka tahu ada caleg perempuan dari baliho atau dari media on line, hanya sebatas tahu tapi belum mengenal lebih dalam program-program caleg perempuan tersebut.

" saya tidak memilih caleg perempuan karena selama masa kampanye tidak ada caleg perempuan yang datang melakukan sosialisasi/ mesimakrama ke banjar saya. Yang datang ke banjar saya hanya caleg laki-laki baik untuk DPR RI, DPRD Provinsi maupun DPRD Kodya. Menurut saya perempuan Bali selain sibuk dengan keluarga juga sibuk dengan adat, susah untuk membagi waktu jika disibukkan lagi sebagai anggota dewan. jadi saya putuskan untuk memilih caleg laki-laki yang kemarin mesimakrama ke banjar saya"

(Responden 126) 
Berikut petikan wawancara mendalam dengan responden laki-laki berusia 20 tahun yang tidak memilih caleg perempuan saat pileg kemarin

"saat pemilu kemarin saya memilih caleg laki-laki, karena menurut saya laki-laki yang lebih cocok meminpin, walaupun saya tahu ada public figure perempuan yang jadi caleg, takutnya kalau dia jadi anggota dewan nanti dia tidak bisa membagi waktu antara tugas dewan dengan tugasnya sebagai ibu rumah tangga dan pebisnis"

(Responden 155)

Dari hasil wawancara terhadap 2 responden tadi tampak bahwa masih terjadi bias gender dalam pemilihan anggota dewan, pemilih khususnya pemilih pemula masih mengangap perempuan tidak cocok berpolitik. Perempuan lebih cocok pada tugas-tugas domestik saja, seperti menyama braya dan kegiatan lain yang berkaitan dengan adat.

Komposisi Jenis kelamin caleg yang dipilih responden dapat dilihat pada Tabel 4.

Tabel 4. Tabulasi Data Pilihan Jenis Kelamin Caleg Berdasarkan jenis Kelamin Responden

\begin{tabular}{|c|c|c|c|}
\hline \multirow[t]{2}{*}{ Jenis Kelamin Caleg } & \multicolumn{2}{|c|}{ Jenis kelamin Responden } & \multirow[t]{2}{*}{ Total } \\
\hline & Perempuan & Laki-laki & \\
\hline \multirow{3}{*}{$\begin{array}{l}\text { Caleg perempuan } \\
\text { Caleg laki-laki } \\
\text { Total }\end{array}$} & 44 & 21 & 65 \\
\hline & 142 & 93 & 235 \\
\hline & 186 & 114 & 300 \\
\hline
\end{tabular}

Sumber: data diolah (2019)

Merujuk pada Tabel 4 tampak bahwa pada Pileg 2019 responden laki-laki maupun perempuan masih lebih memilih caleg laki-laki. Jenis kelamin reponden tidak mempengaruhi mereka dalam memilih. Disini tampak masih terjadi ketimpangan gender, laki-laki selalu lebih mendominasi dalam pemilihan legislatif. Pemilih pemula baik yang perempuan maupun laki-laki tetap lebih memilih caleg laki-laki. Selain alasan permpuan tidak cocok berpolitik, kurangnya informasi tentang profil caleg perempuan yang ikut kontestasi pemilu juga merupakan salah satu faktor responden lebih memilih caleg laki-laki dibanding caleg perempuan. Hasil ini sejalan dengan hasil penelitian (Prihartini, 2018) yang menyatakan bahwa $75 \%$ dari 234 responden pemilih pemula pada pemilu tahun 2014 masih cenderung memilih anggota parlemen laki-laki. Dijelaskan pula bahwa masih ada kesenjangan gender dalam pengetahuan dan preferensi politik pemilih di Indonesia. Pemilih Indonesia baik pemilih pemula maupun pemilih non pemula masih dipengaruhi stereotif gender tentang kemampuan politisi laki-laki dan perempuan untuk mewakili konstituen.

Berikut tabulasi data responden berdasarkan pendidikan dan tabulasi silang antara pendidikan responden dengan jenis kelamin caleg disajikan pada tabel 5 dan tabel 6. 
Tabel 5. Tabulasi Data Berdasarkan Pendidikan Responden

\begin{tabular}{lrr}
\hline \multicolumn{1}{r}{ Pendidikan } & Frekuensi & Persen \\
\hline SMA & 72 & 24,0 \\
Perguruan Tinggi & 228 & 76,0 \\
Total & 300 & 100,0 \\
\hline
\end{tabular}

Sumber: data diolah (2019)

Tabel 6. Tabulasi silang Pendidikan Respenden dengan Jenis Kelamin Caleg Yang Dipilih

\begin{tabular}{lrrr}
\hline Jeni Kelamin Caleg & \multicolumn{2}{c}{ Pendidikan Responden } & Total \\
& SMA & Perguruan Tinggi & \\
\hline Caleg Perempuan & 28 & 37 & 65 \\
Caleg Laki-laki & 44 & 191 & 235 \\
Total & 72 & 228 & 300 \\
\hline
\end{tabular}

Sumber: data diolah (2019)

Merujuk pada tabel 5 dan 6 tampak bahwa pemilih pemula lebih banyak mahasiswa, hal ini terjadi karena siswa SMA yang sudah berumur 17 tahun ada yang belum memiliki KTP atau tidak terdaftar sebagai pemilih tetap. Selain itu belum ada kesadaran dari siswa SMA untuk ikut memilih anggota dewan, mereka masih merasa belum waktunya terlibat dalam pemilu, politik adalah urusan orang yang sudah dewasa. Untuk meningkatkan partisipasi politik generasi muda khusubya yang masih berstatus siswa SMA atau sederajat pemerintah dapat mensosialisasikan pada pelajaran kewarganegaraan di sekolah-sekolah. Pendidikan politik sangat diperlukan generasi muda untuk memunculkan kesadaran dalam berpolitik, ikut serta berpartisipasi menggunakan hak dan kewajibannya sebagai warga Negara. Pendidikan politik juga dapat dilakukan dalam keluarga, di mana orang tua mulai mengarahkan anak untuk ikut memilih partai tertentu atau mengenalkan tokoh-tokoh partai tertentu pada anak. Dapat dilihat pula pendidikan responden mempengaruhi jenis kelamin caleg yang dipilih. Responden dengan pendidikan Perguruan tinggi lebih cenderung memilih caleg laki-laki. Pemilih pemula yang berstatus mahasiswa sudah mulai banyak bergaul sehingga sudah mendapat informasi tentang partai politik maupun caleg yang diusung partai politik menyebabkan mereka lebih antusias untuk ikut berpartisipasi dalam pileg.

Tabulasi data keaktifan responden dalam berorganisasi disajikan pada tabel 7, sedangkan tabulasi silang antara jenis kelamin caleg pilihan responden dengan keaktifan organisasi dapat dilihat di tabel 8. Keaktifan organisasi mempengaruhi jenis kelamin caleg yang dipilih. Dalam organisiasi pemilih pemula bisa mendapatkan informasi tentang tokoh-tokoh politik dari temantemannya maupun senior-seniornya yang lebih berpengalaman. Generasi muda yang aktif diorganisasi seperti organisasi seka teruna teruni di banjar-banjar, maupun organisasi kemahasiswaan seperti BEM, dapat menumbuhkan minat politik generasi muda serta mulai menyadari pentingnya kesetaraan gender dalam semua aspek kehidupan.

Tabel 7. Tabulasi Data Keaktivan Organisasi Responden

\begin{tabular}{lcc}
\hline Keaktivan & Frekuensi & Persen \\
\hline Ya & 172 & 57,3 \\
Tidak & 128 & 42,7 \\
Total & 300 & 100,0 \\
\hline
\end{tabular}

Sumber: data diolah (2019)

Tabel 8. Tabulasi Silang Keaktivan Organisasi dengan Jenis Kelamin Caleg

\begin{tabular}{lccr}
\hline & \multicolumn{2}{c}{ Keaktivan Organisasi } & Total \\
\cline { 2 - 3 } & Ya & Tidak & \\
\hline Caleg perempuan & 27 & 38 & 65 \\
Caleg laki-laki & 145 & 90 & 235 \\
Total & 172 & 128 & 300 \\
\hline
\end{tabular}


Langkah selanjutnya adalah melihat apakah jenis kelamin, umur, pekerjaan responden, pekerjaan ayah, pekerjaan ibu serta keaktifan responden berorganisasi mempengaruhi pilihan jenis kelamin caleg yang dipilih dalam pileg 2019 untuk itu kami menggunakan metode regresi logistic biner. Model umum regersi logistic biner adalah

$$
g(x)=\ln \left(\frac{\pi(x)}{1-\pi(x)}\right)=\beta_{0}+\beta_{1} x_{1}+\beta_{2} x_{2}+\beta_{3} x_{3}+\beta_{4} x_{4}+\beta_{5} x_{5}+\beta_{6} x_{6}
$$

Langkah awal adalah melakukan Uji signifikansi parameter secara simultan untuk mengetahui apakah variabel prediktor memberikan pengaruh yang signifikan terhadap model. Hipotesis yang digunakan adalah:

$H_{0}: \beta_{1}=\beta_{2}=\beta_{3}=\beta_{4}=\beta_{5}=\beta_{6}=0$ (variabel prediktor tidak memberikan pengaruh yang signifikan terhadap model)

$H_{1}: \beta_{i} \neq 0, i=1,2,3,4,5,6$ (minimal terdapat satu variabel prediktor yang berpengaruh signifikan terhadap model).

Statistik uji yang digunakan adalah Chi kuadrat , Hipotesis nol ditolak jika nilai signifikansi $<\alpha=0.10$. Dengan bantuan software SPSS 21 diperoleh nilai Chi kuadrat $=28.623$ dan nilai signifikansi 0.00 sehingga dapat disimpulkan minimal ada satu variabel predictor yang berpengaruh signifikan. Hasil Hosmer dan Lemeshow test menunjukkan model regersi logistic mampu menjelaskan data dan tidak terdapat perbedaan antara model dengan nilai observasinya, berarti model regersi logistic dapat digunakan untuk menjelaskan hubungan antara variabel predictor dengan variabel respon.

Selanjutnya untuk melihat variabel prediktor yang mana saja yang berpengaruh secara signifikan pada model dilanjutkan dengan melakukan uji parsial dengan hipotesis sebagai berikut

$$
\begin{aligned}
& H_{0}: \beta_{g 1}=0 \\
& H_{1}: \beta_{g 1} \neq 0
\end{aligned}
$$

Tolak $\mathrm{H}_{0}$ jika nilai statistik uji Wald $<\left|\mathrm{Z}_{(\alpha / 2)}\right|$ atau nilai $p$-value $<\alpha$. Hasil lengkap dapat dilihat pada Tabel 9.

Tabel 9. Variabel Yang Masuk Dalam Model

\begin{tabular}{lrrrrrr}
\hline & B & S.E. & Wald & $\begin{array}{c}\text { Derajat } \\
\text { bebas }\end{array}$ & $\begin{array}{c}\text { Signifi } \\
\text { kansi }\end{array}$ & Exp(B) \\
\hline X3 & 1,311 & 0,313 & 17.517 & 1 & 0,000 & 3,708 \\
X6 & $-0,957$ & 0,300 & 10.199 & 1 & 0,001 & 0,384 \\
konstanta & $-0,479$ & 0,533 & .808 & 1 & 0,369 & 0,619 \\
\hline \multicolumn{7}{c}{ Sumber: data diolah (2019) }
\end{tabular}

Memperhatikani Tabel 9 jika digunakan tingkat signifikansi 10\% model logit yang terbentuk adalah:

$$
g(x)=-0,479+1,311 x_{3}-0,957 x_{6}
$$

Dari persamaan (4) diperoleh bahwa variabel pendidikan dan keaktifan organisasi berpengaruh signifikan terhadap jenis kelamin caleg yang dipilih. Interpretasi odds rasio dapat dijelaskan sebagai berikut: responden dengan pendidikan perguruan tinggi berpeluang memilih caleg laki-laki sebesar 3,708 kali dibandingkan pendidikan SMA, dilain pihak semakin aktif responden dalam organisasi, peluang memilih caleg laki-laki 0.384 dibandingkan caleg perempuan, artinya jika pemilih pemula aktif diorganisasi peluang memilih caleg perempuan lebih tinggi dibandingkan pemilih yang tidak aktif dalam organisasi. Responden yang aktif di organisasi lebih terbuka wawasan politik mereka. 


\section{Simpulan dan saran}

Gender masih menjadi penentu pilihan responden pada pileg 2019, responden masih beranggapan bahwa laki-laki lebih cocok menjadi anggota dewan. Alasan responden tidak memilih caleg perempuan diantaranya: jumlah caleg perempuan sedikit, laki-laki lebih cocok sebagai pemimpin, perempuan Bali sibuk dengan urusan adat sehingga sulit membagi waktu, kurangnya sosialisasi caleg perempuan ke Banjar-banjar. Faktor yang berpengaruh terhadap cara berpikir responden dalam memilih caleg adalah pendidikan dan keaktifan dalam berorganisasi.

Untuk meningkatkan keterpilihan perempuan di legislatif, sebaiknya kader-kader partai lebih sering berdiskusi/bersosialisasi dengan organisasi-organisasi kepemudaan baik di kampus maupun di banjar-banjar.

\section{Ucapan terimakasih}

Pada kesempatan ini kami mengucapkan terima kasih kepada Rektor Universitas Udayana yang telah memberikan dana penelitian melalui BLU Universitas Udayana TA 2019 sesuai dengan Surat Perjanjian Penugasan Pelaksanaan Penelitian Unggulan Program DIPA Studi Nomor: 2008/UN14.2.8.II/LT/2019.

\section{Daftar Rujukan}

Adelina, N. 2016. Keterwakilan Perempuan di Dewan Perwakilan Rakyat Daerah Provinsi Sumatra Utara Periode 2009-2014. ADIL: Jurnal Hukum Vol. 7 No.2, 222-242.

Agustina, T. 2014. Perjalanan Perempuan Indonesia dalam "Mengejar" Kuota Kursi Parlemen. Mu'adalah Jurnal Studi Gender dan Anak Vol. II No. 1, 36-52.

Budiarti, A. 2011. Bayang-bayang Afirmasi Keterwakilan Perempuan di Parlemen Indonesia. Studi Politik No 2, Vol 1, 97-112.

Hartono, Y. dan Putri, E.M.C. 2015. Pandangan pemilihan Pemula Terhadap Pemilihan Umum di Indonesia. JUSTITIA ET PAX Jurnal Hukum Volume 31 Nomor 2, DOI: https://doi.org/10.24002/jep.v31i2.1346, 87-106.

Hosmer, D.W. and Lemeshow,S. 2000. Applied Logistic Regression. Second Edition. New York: John Willey \& Sons.

Karika, I. 2017. Eksistensi Perempuan Bali Dalam Politik . Jurnal Kajian Pendidikan Widya Accarya FKIP Universitas Dwijendra, 1-20.

Kelana, N. 2019, April 16. Pemilih Pemula dan Pentingnya dalam Pemilu. Retrieved from https://siedoo.com/berita-19437-pemilih-pemula-dan-pentingnya-dalam-pemilu/.

KPU. 2014. Buku Data dan Infografik Pemilu Anggota DPR RI \& DPD RI 2014. Retrieved from https://www.kpu.go.id/koleksigambar/Buku_Pemilu_2014_Dalam_Angka_ACC_Upload.p df.

Krook, M. 2010. Why Are Fewer Women than Men Elected? Gender and the Dynamics of Candidate Selection. POLITICAL STUDIES REVIEW, VOL 8. doi: 10.1111/j.1478-9302.2009.00185.x, 155-168.

Menteri PPA, RI. 2015. Peraturan Menteri Pemberdayaan Perempuan Dan Perlindungan Anak Republik Indonesia No 10 tahun 2015. Jakarta: Berita Negara Republik Indonesia Tahun 2015 Nomor 1531.

Nur Wardhani, P. 2018. Partisipasi Politik Pemilih Pemula dalam Pemilihan Umum. Jurnal Pendidikan Ilmu-Ilmu Sosial 10 (1). DOI: 10.24114/jupiis.v10i1.8407, 57-62.

Prasetyo, W. 2019. Political Participation Of Beginner Voters In General Election 2019 In Kelurahan Sumber Kecamatan Banjarsari Kota Surakarta. Civics Education And Social Science Journal (CESSJ). Vol 1 Nomor 1, 86-105.

Prihartini, E. 2018. Indonesian Young Voters: Political Knowledge and Electing. Women's Studies International Forum. DOI: 10.1016 / j.wsif.2018.07.015, 46-52.

Ras A Gelgel, N.M. dan Apriani, K.D. (2019). Rendahnya Keterpilihan Perempuan pada Pemilu 2019 di Bali. JURNAL KAJIAN BALI Vol. 09, No. 02, 263-288.

Saputra, R. 2017. Partisipasi Politik Pemilih Pemula Pada Pemilihan Presiden DI Kecamatan Mandau Kabupaten Bengkalis Tahun 2014. JOM FISIP Vol. 4 No. 1, 1-12. 
Subono, N. 2009. Menuju Representasi Politik Perempuan yang lebih Bermakna. Jurnal Sosial Demokrasi, Edisi 6 tahun 2, 52-55.

Wardani, S. B. 2011. Representasi Politik Perempuan (Masih) Setengah Hati; Analisis Keterpilihan Perempuan Hasil Pemilu 2009 dan Tantangan Advokasi Menuju Pemilu 2014. Studi Politik No 2, Vol.1, 158-173.

Yudha, 0. 2018. Optimalisasi Kuota Perempuan di Parlemen Berdasarkan Putusan Mahkamah Konstitusi NOMOR 22-24/PUU-VI/2008. HUKUM BISNIS, Volume 2 No 1, 111-127.

Zamhasari. 2017. Building Beginner Voter's Interest in Political Participation in Indonesia's Election. Advances in Social Science, Education and Humanities Research (ASSEHR), volume 163, 54-57. 